\title{
PENGARUH DUKUNGAN SELEBRITI, KEPERCAYAAN, DAN PEMASARAN DARI MULUT KE MULUT SECARA ELEKTRONIK TERHADAP NIAT BELI PENGGUNA SHOPEE DI JAKARTA
}

\author{
Willyana Cendrawati Dan Carunia Mulya Firdausy \\ Program Studi S1 Manajemen Fakultas Ekonomi \& Bisnis Universitas Tarumanagara, Jakarta \\ Willyana.115160418@stu.untar.ac.id \\ caruniaf@pps.untar.ac.id
}

\begin{abstract}
This study aims at examining the influences of celebrity endorsement, trust, and eWOM on purchase intentions of shopee users in Jakarta. The population of this study were 300 respondents who used the Shopee application in Jakarta. The convenience sampling method is used by distributing questionnaires online which are then processed using the SPSS version 25 program. The results showed that celebrity support had no significant influence effec tothe purchase intention of shopee users in Jakarta, while trust and e-WOM had significant and positive influences to the purchase intention of Shopee application users in Jakarta. Therefor, Shopee needs to pay attention to those two variables to improve purchase intention of their products' users.
\end{abstract}

Keywords: Celebrity Endorsement, Trust, Electronic Word Of Mouth, Purchase Intention, Shopee.

\begin{abstract}
Abstrak: Penelitian ini bertujuan untuk menguji pengaruh dukungan selebriti, kepercayaan, dan pemasaran dari mulut ke mulut secara elektronik terhadap niat beli pengguna shopee di Jakarta. Populasi dari penelitian ini adalah 300 responden yang menggunakan aplikasi shopee di Jakarta. Metode convenience sampling digunakan dengan menyebarkan kuesioner secara online yang kemudian diolah menggunakan bantuan program SPSS versi 25 . Hasil penelitian menunjukkan bahwa dukungan selebriti tidak berpengaruh signifikan terhadap niat beli pengguna Shopee di Jakarta, sedangkan kepercayaan dan Pemasaran dari Mulut ke Mulut Secara Elektronik berpengaruh signifikan dan positif terhadap niat beli pengguna aplikasi Shopee di Jakarta. Oleh karena itu, Shopee perlu memperhatikan kedua variabel tersebut untuk meningkatkan niat beli pengguna produknya.
\end{abstract}

Kata kunci: Dukungan Selebriti, Kepercayaan, e-WOM, Niat beli, Shopee.

\section{LATAR BELAKANG}

Seiring berjalannya waktu, Peran perkembangan teknologi di era globalisasi menjadi sangat penting karena membantu banyak pekerjaan manusia dalam melakukan berbagai aktivitas kehidupan (Laurent, 2016). Kehadiran jaringan telepon di mana-mana telah menghasilkan pertumbuhan sistem perdagangan elektronik (e-commerce) melalui perangkat genggam (Mahatanankoon, 2007).

Berbeda dari kegiatan berbelanja yang dulunya selalu kita lakukan dengan cara mendatangi toko secara fisik yang memerlukan banyak waktu dan usaha, sekarang dengan berkembangnya teknologi internet kita dapat berbelanja melalui e-commerce tanpa perlu melakukan tatap muka. Menurut Grandona dan Pearson (2004) e-commerce adalah proses pembelian dan penjualan produk atau layanan menggunakan data elektronik melalui Internet, Internet sudah 
menjadi salah satu kebutuhan banyak orang termasuk masyarakat Indonesia yang setiap tahun angka pengguna internet selalu naik.

Berdasarkan Gambar 1, info terkini oleh We Are Social melalui inet.detik.com, terdapat kenaikan $17 \%$ atau sebanyak 25 juta dari tahun 2019 menjadi 175,4 juta orang pengguna yang mengakses internet di Indonesia pada tahun 2020, setengah dari masyarakat Indonesia sudah mengakses internet dari total penduduk Indonesia yang berjumlah 272,1 juta jiwa, dapat disimpulkan internet akan semakin dikenal dan digunakan oleh lebih banyak orang untuk beberapa tahun ke depan.

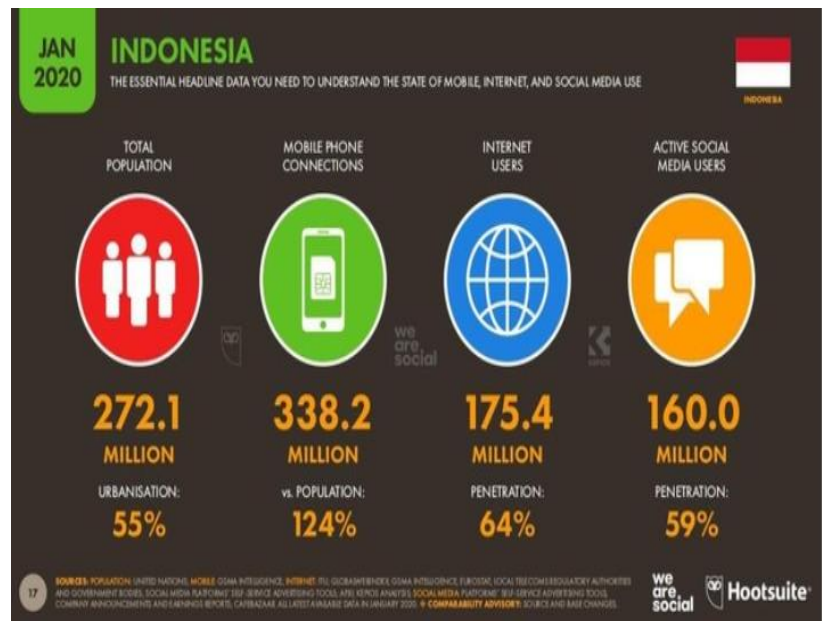

Gambar 1

Pengguna Internet di Indonesia, Januari 2020

(Sumber: We are social (inet.detik.com ))

Perdagangan elektronik (e-commerce) telah menjadi salah satu perkembangan paling signifikan di dunia bisnis. Salah satu e-commerce yang sudah dikenal oleh banyak orang di Indonesia adalah Shopee, yaitu aplikasi yang menduduki peringkat pertama jumlah pengguna yang aktif dan juga peringkat pertama untuk aplikasi yang telah diunduh pada tahun 2019.

Naiknya Niat beli masyarakat terhadap aplikasi Shopee ini menarik untuk diteliti lebih lanjut. Dalam literatur dinyatakan bahwa Niat beli ini dipengaruhi beberapa faktor yakni faktor Dukungan Selebriti, Kepercayaan dan Pemasaran dari Mulut ke Mulut Secara Elektronik. Menurut Ohanian dalam Liu and Liu ( 2019 ), Celebrity endorsement memiliki daya tarik dan mampu mempromosikan produk dengan baik sehingga dapat meningkatkan minat beli seseorang yang melihat iklan dan menumbuhkan niat untuk membeli produk yang diiklankan.

Kepercayaan selalu dianggap sebagai faktor paling penting, dalam merangsang pembelian melalui internet, yang diakui secara positif untuk memengaruhi niat konsumen maya dan Kepercayaan dapat dianggap sebagai keyakinan yang signifikan yang menciptakan sikap positif menuju Niat beli (Jarvenpaa, et. al, 2000).

Lee dkk. (2011) meneliti dan menyimpulkan bahwa niat pembelian dapat di tingkatkan dengan cara menguatkan kredibilitas yang dirasakan oleh konsumen dalam ulasan online produk atau Pemasaran dari Mulut ke Mulut Secara Elektronik yang positif dan berisi komentar baik dapat meningkatkan keinginan untuk berbelanja contohnya adalah ulasan suatu pengguna tentang suatu produk yang sedang ditelusuri, Berdasarkan uraian tersebut maka dapat disimpulkan bahwa Pemasaran dari Mulut ke Mulut Secara Elektronik memiliki pengaruh positif terhadap Niat beli . 
Berdasarkan latar belakang di atas, studi ini bertujuan mengkaji Pengaruh Dukungan Selebriti, Kepercayaan dan Pemasaran dari Mulut ke Mulut Secara Elektronik terhadap Niat beli pengguna Shopee di Jakarta.

\section{LANDASAN TEORI}

Landasan teori penelitian ini yakni Teori planned behavior yang digagas oleh Ajzen (1991). Theory of planned behavior dapat dijadikan sebagai teori acuan untuk memahami perilaku konsumen dalam hal niat pembelian suatu produk.

Dalam teori tersebut dijelaskan bahwa niat pembelian dipengaruhi oleh berbagai faktor. diantara faktor tersebut yakni faktor Dukungan Selebriti, Kepercayaan dan Pemasaran dari Mulut ke Mulut Secara Elektronik. Dukungan Selebriti dapat didefiniskan sebagai individu yang menikmati pengakuan publik dan menggunakan pengakuan dari konsumen dengan cara tampil dengan beriklan ( McCracken, dalam Kok 2013). Sedangkan Kepercayaan merupakan keadaan psikologis yang terdiri dari niat untuk menerima kerentanan berdasarkan ekspektasi positif dari niat atau perilaku orang lain ( Rousseau dkk, 1998). Pemasaran dari Mulut ke Mulut Secara Elektronik merupakan Kegiatan rujukan lisan secara elektronik dalam tujuan yang ditentukan, pencarian informasi, proses seleksi dan proses pengambilan keputusan setelah pembelian oleh pelanggan, yang ditandai dengan permintaan dan berbagi informasi tentang bisnis produk tersebut di media sosial ( Zhang dkk, 2014).

Niat beli merupakan kemungkinan bagi konsumen untuk membeli produk yang ditawarkan oleh sebuah agen tur, kemungkinan konsumen mempertimbangkan untuk membeli produk yang ditawarkan, kemungkinan konsumen untuk merekomendasikan produknya kepada orang lain, dan kemungkinan konsumen untuk membeli produk tersebut ( Doods dkk, 1991). Oleh karena itu kerangka pemikiran penelitian ini sebagai berikut (Lihat Gambar 2).

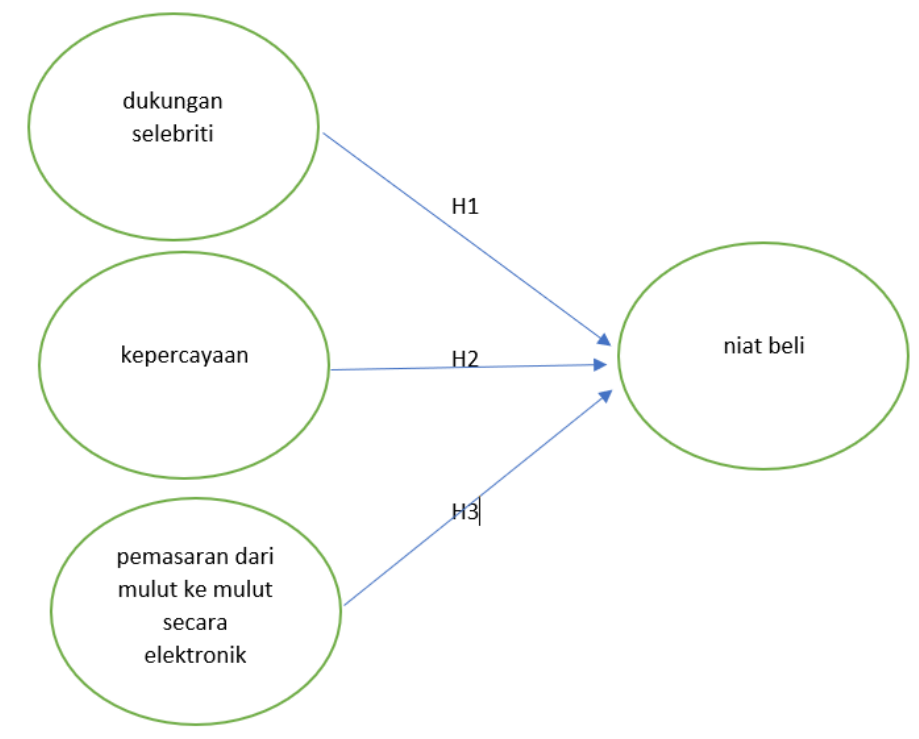

Gambar 2. Kerangka Pemikiran

Berdasarkan kerangka pemikiran di atas, dapat disusun hipotesis penelitian sebagai berikut:

H1: Dukungan Selebriti dapat memprediksi secara positif Niat beli Shopee di Jakarta.

H2 : Kepercayaan dapat memprediksi secara positif Niat beli Shopee di Jakarta. 
H3: Pemasaran dari Mulut ke Mulut Secara Elektronik dapat memprediksi secara positif Niat beli Shopee di Jakarta.

\section{METODE PENELITIAN}

Desain penelitian ini menggunakan desain deskriptif yakni mendeskripsikan sifat atau karakteristik suatu gejala atau peristiwa ( Malholtra (2010)). Peristiwa yang akan diselidiki adalah nilai-nilai yang terkandung dalam suatu hubungan antar satu faktor dengan faktor lain. Dalam desain penelitian ini, metode statik yang digunakan adalah kuesioner dan akan disebar kepada pengguna aplikasi shopee di wilayah Jakarta.

Populasi dalam penelitian ini adalah pengguna aplikasi Shopee yang berdomisili di wilayah Jakarta. Teknik pemilihan sampel menggunakan teknik non probability sampling. Teknik non probability sampling adalah teknik dalam pemilihan sampel dimana setiap populasi tidak memiliki kesempatan yang sama untuk terpilih sebagai sampel (Malhotra, 2015). Dalam penelitian ini digunakan teknik pemilihan sampel jenis convenience sampling karena ada pertimbangan kriteria tertentu yaitu berdomisili di Jakarta dan memiliki aplikasi Shopee. Alasan digunakan teknik convenience sampling dalam penelitian ini karena adanya keterbatasan waktu yang dimiliki dan biaya yang dikeluarkan lebih terjangkau.

Ukuran sampel yang diambil Sebanyak 300 responden. Kriteria responden dalam penelitian ini merupakan orang - orang yang mengetahui aplikasi Shopee di wilayah Jakarta, sampel di kumpulkan dengan cara menyebarkan link kuesioner melalui media sosial Instagram dan pengumpulan data dilakukan menggunakan kuesioner. Dalam mengkuantifikasi data untuk masing-masing item/indikator variable digunakan dengan skala likert 1-5. Score indikator dari skala likert 1-5, yaitu:

1. $\quad$ STS $=$ Sangat Tidak Setuju

2. $\quad$ TS $=$ Tidak Setuju

3. $\quad \mathrm{N}=$ Netral

4. $\quad \mathrm{S}=$ Setuju

5. $\quad$ SS $=$ Sangat Setuju

\section{HASIL ANALISIS DATA}

\section{Hasil Analisis Validitas}

Uji validitas merupakan pengujian yang dilakukan untuk mengetahui seberapa baik instrumen pengukuran yang digunakan dalam penelitian. Skor yang dibandingkan untuk menentukan valid atau tidaknya pertanyaan adalah corrected item-total correlation. Apabila skor corrected item-total correlation lebih besar dari 0,3 maka pernyataan tersebut dinyatakan valid. Hasil uji validitas dapat dilihat dalam Tabel 1.

Tabel 1. Hasil Uji Validitas

\begin{tabular}{|c|c|c|}
\hline \multicolumn{2}{|c|}{ Corrected item-total correlation } & Keterangan \\
\hline \multicolumn{3}{|c|}{ Dukungan Selebriti } \\
\hline CE1 & 0.684 & Valid \\
\hline CE2 & 0.660 & Valid \\
\hline
\end{tabular}


Cendrawati Dan Firdausy: Pengaruh Dukungan Selebriti, Kepercayaan, Dan ...

\begin{tabular}{|c|c|c|}
\hline CE3 & 0.564 & Valid \\
\hline CE4 & 0.636 & Valid \\
\hline CE5 & 0.664 & Valid \\
\hline \multicolumn{3}{|c|}{ Kepercayaan } \\
\hline T1 & 0.686 & Valid \\
\hline T2 & 0.686 & Valid \\
\hline T3 & 0.625 & Valid \\
\hline T4 & 0.718 & Valid \\
\hline T5 & 0.645 & Valid \\
\hline \multicolumn{3}{|c|}{ Pemasaran dari Mulut ke Mulut Secara Elektronik } \\
\hline e-WOM1 & 0.446 & Valid \\
\hline e-WOM2 & 0.503 & Valid \\
\hline e-WOM3 & 0.479 & Valid \\
\hline e-WOM4 & 0.498 & Valid \\
\hline PI1 & Niat beli & Valid \\
\hline P12 & 0.665 & Valid \\
\hline P13 & 0.700 & Valid \\
\hline PI4 & 0.713 & Valid \\
\hline
\end{tabular}

Tabel 1 menampilkan hasil uji validitas kepada 300 responden dan menunjukkan bahwa seluruh pernyataan memiliki nilai Corrected item-total correlation diatas 0.3. Dengan demikian, seluruh variabel dinyatakan valid sehingga dapat digunakan sebagai variabel penelitian.

\section{Hasil Analisis Reliabilitas}

Uji reliabilitas digunakan untuk mengetahui konsistensi hasil sebuah jawaban terhadap koresponden, suatu variabel dikatakan reliabel jika nilai Cronbach Alpha >0,6. Uji reliabilitas dilakukan dengan menggunakan program SPSS. hasil uji terhadap 300 responden pada tabel 4.12 menunjukkan keempat variabel yang digunakan dalam penelitian ini reliabel karena memiliki nilai Cronbach's Alpha di atas 0,6.

Tabel 2. Hasil Uji Reliabilitas

\begin{tabular}{|c|c|}
\hline Variabel & Cronbach Alpha \\
\hline Dukungan Selebriti & 0.837 \\
\hline Kepercayaan & 0.855 \\
\hline e-WOM & 0.682 \\
\hline Niat beli & 0.850 \\
\hline
\end{tabular}

Tabel 2 menampilkan hasil uji reliabilitas kepada 300 responden dan menunjukkan bahwa seluruh pernyataan memiliki nilai Cronbach's Alpha di atas 0.6. Dengan 
demikian,seluruh variabel dinyatakan reliabel sehingga dapat digunakan sebagai instrumen penelitian.

\section{Hasil Uji Asumsi Klasik \\ Hasil Uji Normalitas}

Uji normalitas ini dilakukan untuk mengetahui apakah distribusi dari model regresi variabel dependen dan variabel independen normal atau tidak. Pengujian akan dilakukan menggunakan p-plot, data dapat dinyatakan terdistribusi dengan normal bila grafik p-plot membentuk titik - titik data yang menyebar mendekati atau menempel pada garis diagonal dan membentuk huruf S (S line),

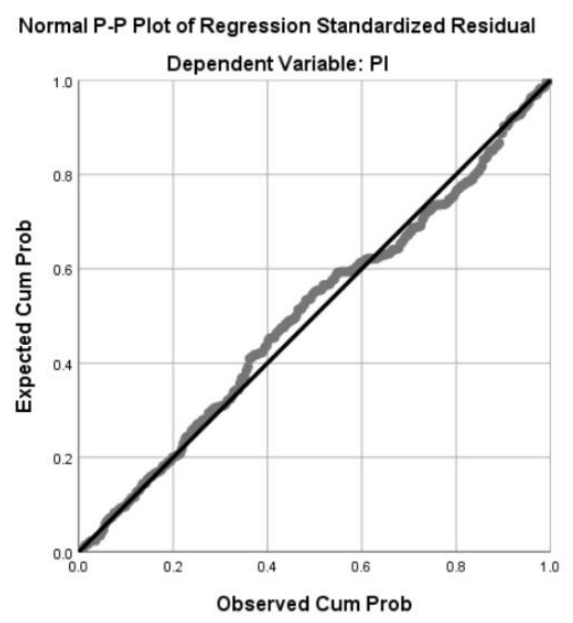

Gambar 3

Hasil Uji Normalitas Pengaruh Dukungan Selebriti, Kepercayaan dan Pemasaran dari Mulut ke Mulut Secara Elektronik Terhadap Niat beli Berdasarkan gambar 3 di atas, hasil uji normalitas yang dengan menggunakan P-plot menghasilkan titik-titik menyebar mendekati atau menempel pada garis diagonal dan membentuk huruf $S$, sehingga dapat disimpulkan bahwa model regresi di atas berdistribusi normal.

\section{Hasil Uji Multikolinearitas}

Menurut Ghozali (2016), Uji multikolinieritas ini dilakukan untuk mengetahui apakah terjadi korelasi antara variabel bebas, bila nilai VIF (Variance Inflation Factor) <10 maka tidak terdapat multikolinearitas antara variabel bebas ( Lihat tabel 3).

Tabel 3. Hasil Uji Multikolinieritas Pengaruh Dukungan Selebriti, Kepercayaan dan Pemasaran dari Mulut ke Mulut Secara Elektronik Terhadap Niat beli

\begin{tabular}{|c|c|c|}
\hline Variabel & VIF & Kesimpulan \\
\hline Dukungan Selebriti & 1.220 & Tidak terdapat multikolineritas \\
\hline
\end{tabular}


Cendrawati Dan Firdausy: Pengaruh Dukungan Selebriti, Kepercayaan, Dan ...

\begin{tabular}{|c|c|c|}
\hline Kepercayaan & 1.242 & Tidak terdapat multikolineritas \\
\hline $\begin{array}{c}\text { Pemasaran dari Mulut ke } \\
\text { Mulut Secara Elektronik }\end{array}$ & 1.166 & Tidak terdapat multikolineritas \\
\hline
\end{tabular}

Tabel 3 menampilkan hasil uji Multikolinearitas dan menunjukkan bahwa seluruh variabel tersebut memiliki nilai VIF $<10$. Sehingga ketiga variabel diatas dinyatakan tidak terdapat multikoliniearitas

\section{Hasil Uji heteroskedastisitas}

Hasil uji heterokedastisitas yang dilakukan dengan mengamati output scatterplot menggunakan SPSS versi 25 dan menghasilkan titik-titik yang penyebarannya tidak membentuk pola, Maka dari seluruh uji asumsi klasik, dapat disimpulkan bahwa analisis regresi yang digunakan pada persamaan pengaruh Dukungan Selebriti, Kepercayaan dan Pemasaran dari Mulut ke Mulut Secara Elektronik terhadap Niat beli telah dilakukan dengan baik dan ideal sehingga telah memenuhi persyaratan data yang baik (Lihat Gambar 4).

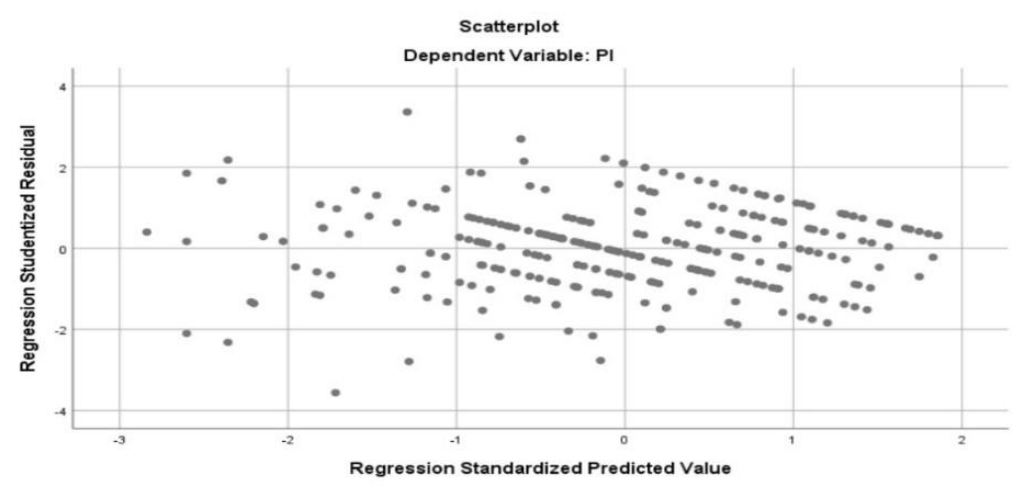

Gambar 4.

Hasil Uji Pengaruh Dukungan Selebriti, Kepercayaan dan Pemasaran dari Mulut ke Mulut Secara Elektronik Terhadap Niat beli

Berdasarkan gambar di atas, Titik-titik tersebar di sekitar garis diagonal sehingga

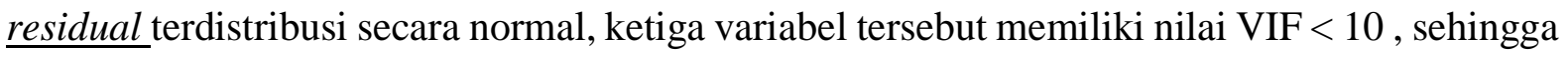
tidak terdapat multikolinearitas dan Tidak terjadi heteroskedastisitas.

\section{Hasil Analisis Regresi Ganda}

Hasil analisis regresi ganda dapat disimpulkan bahwa Dukungan Selebriti dapat memprediksi secara positif terhadap Niat beli , namun Kepercayaan dan Pemasaran dari Mulut ke Mulut Secara Elektronik tidak dapat memprediksi secara positif terhadap Niat beli.Tabel 4.Hasil Analisis Regresi Ganda Dukungan Selebriti, Kepercayaan dan Pemasaran dari Mulut ke Mulut Secara Elektronik Terhadap Niat beli

\begin{tabular}{|c|c|c|c|}
\hline Model & Unstandardized & t & Sig. \\
\hline
\end{tabular}


Cendrawati Dan Firdausy: Pengaruh Dukungan Selebriti, Kepercayaan, Dan ...

\begin{tabular}{|c|c|c|c|}
\hline & Coefficients & & \\
\cline { 2 - 3 } & B & & \\
\hline Constant & 0.087 & 0.086 & 0.932 \\
\hline Dukungan Selebriti & 0.047 & 1.380 & 0.169 \\
\hline Kepercayaan & 0.458 & 11.207 & 0.000 \\
\hline e-WOM & 0.269 & 6.104 & 0.000 \\
\hline
\end{tabular}

\section{Hasil Uji Koefisien Determinasi (R2).}

Untuk hasil uji koefisien determinasi (r2) diperoleh bahwa nilai sebesar 0,477. Artinya, sebesar 47.7\% variabel dependen (Niat beli) dapat dijelaskan oleh variabel independen ( Dukungan Selebriti, Kepercayaan dan Pemasaran dari Mulut ke Mulut Secara Elektronik). Sedangkan sisanya sebesar $52.3 \%$, maka nilai $R$-Square tersebut tergolong sedang (Lihat Tabel 5)

Tabel 5.Hasil Uji Koefisien Determinasi Ganda Dukungan Selebriti, Kepercayaan dan Pemasaran dari Mulut ke Mulut Secara Elektronik Terhadap Niat beli

\section{Hasil Uji F}

\begin{tabular}{|c|c|}
\hline Model & Adjusted $R$ Square \\
\hline 1 & 0.477 \\
\hline
\end{tabular}

Pada tabel 6 di bawah diketahui bahwa, nilai sig sebesar 0.000 dan berada di bawah 0,05, maka Ho ditolak dan dapat disimpulkan setidaknya salah satu dari variabel independen merupakan prediktor terhadap variabel dependen secara bersamaan. Artinya salah satu dari variabel Dukungan Selebriti, Kepercayaan dan Pemasaran dari Mulut ke Mulut Secara Elektronik merupakan prediktor Terhadap Niat beli .(Lihat Tabel 4.16)

Tabel 6.Hasil Uji F Variabel Dukungan Selebriti, Kepercayaan dan Pemasaran dari Mulut ke Mulut Secara Elektronik Terhadap Niat beli

\begin{tabular}{|c|c|c|c|c|c|}
\hline Model & $\begin{array}{c}\text { Sum of } \\
\text { Squares }\end{array}$ & df & $\begin{array}{c}\text { Mean } \\
\text { Square }\end{array}$ & F & Sig. \\
\hline Regression & 901.851 & 3 & 300.617 & 91.959 & 0.000 \\
\hline Residual & 967.629 & 296 & 3.269 & & \\
\hline Total & 1869.480 & 299 & & & \\
\hline
\end{tabular}

\section{Hasil Uji t}

Uji-t dilakukan untuk mengetahui secara parsial pengaruh variabel bebas terhadap variabel terikat, dengan asumsi bahwa variabel lainnya itu dianggap konstan. Tingkat

keyakinan yang digunakan yaitu 95\% atau (a) =0,05 Apabila nilai signifikansi $(\operatorname{sig})>\mathrm{a}$, artinya tidak terdapat pengaruh dari variabel bebas terhadap variabel terikat. (Malhotra, 20 10), Dari hasil pengujian analisis regresi berganda pada tabel 4, disimpulkan hipotesis sebagai berikut. 
Pertama, Dukungan Selebriti tidak berpengaruh terhadap Niat beli pengguna Shopee di Jakarta. Kedua, Kepercayaan berpengaruh terhadap Niat beli pengguna Shopee di Jakarta. Ketiga, Pemasaran dari Mulut ke Mulut Secara Elektronik juga berpengaruh positif terhadap Niat beli pengguna Shopee di Jakarta. Keempat, Pengaruh ketiga variable secara bersamasama dapat disimpulkan bahwa Dukungan Selebriti tidak terdapat pengaruh terhadap Niat beli pengguna Shopee di Jakarta. Sedangkan Kepercayaan dan Pemasaran dari Mulut ke Mulut Secara Elektronik berpengaruh secara signifikan terhadap Niat beli pengguna Shopee di Jakarta. Sehingga hal tersebut bertentangan dengan hasil Rennae Daneshvary (2000) yang menunjukkan endorsement memiliki dampak yang signifikan terhadap Niat beli namun sejalan dengan hasil penelitian Xiao Tong dan Jin Su ( 2018 ) menunjukkan kepercayaan memiliki efek positif pada niat beli konsumen dan Hasil penelitian Mohammed T. Nuseir ( 2019 ) menunjukkan Pemasaran dari Mulut ke Mulut Secara Elektronik memiliki dampak yang signifikan terhadap Niat beli . Maka dapat disimpulkan bahwa aplikasi Shopee harus memilih selebritas yang berkompeten dan kredibel karena tidak semua selebriti dapat mempengaruhi minat beli konsumen, kepercayaan konsumen juga memegang peran penting dalam transaksi pada aplikasi Shopee sehingga Shopee harus terus menjaga kepercayaan yang sudah dibangun antar konsumen. Pemasaran dari Mulut ke Mulut Secara Elektronik juga memiliki dampak yang sangat besar bagi keputusan pembelian, sehingga Shopee harus terus menjaga kualitas produk yang beredar di aplikasi Shopee sehingga dapat meningkatkan review positif pada ulasan dan meningkatkan niat beli konsumen.

\section{KESIMPULAN}

Berdasarkan hasil dan pembahasan di atas dapat disimpulkan sebagai berikut:

1. Dukungan Selebriti tidak berpengaruh signifikan terhadap Niat beli pengguna Shopee di Jakarta.

2. Kepercayaan berpengaruh secara signifikan terhadap Niat beli pengguna Shopee di Jakarta.

3. Pemasaran dari Mulut ke Mulut Secara Elektronik berpengaruh secara signifikan terhadap Niat beli pengguna Shopee di Jakarta, sehingga aplikasi Shopee harus terus aktif dalam memicu konsumen untuk terus memberikan ulasan online dan meningkatkan niat beli. 


\section{DAFTAR PUSTAKA}

Liu, Y. and Liu, M.T. (2019), "Celebrity poses and consumer attitudes in endorsement advertisements", Asia Pacific Journal of Marketing and Logistics, Vol. 31 No. 4, pp. 1027-1041. https://doi.org/10.1108/APJML-07-2018-0270

Chen, S. and Huddleston, P. (2009), "A comparison of four strategies to promote fair trade products", International Journal of Retail \& Distribution Management, Vol. 37 No. 4, pp. 336-345. https://doi.org/10.1108/09590550910948565

Chen, S. and Huddleston, P. (2009), "A comparison of four strategies to promote fair trade products", International Journal of Retail \& Distribution Management, Vol. 37 No. 4, pp. 336-345. https://doi.org/10.1108/IJSMS-14-03-2013-B002

Chen, S. and Huddleston, P. (2009), "A comparison of four strategies to promote fair trade products", International Journal of Retail \& Distribution Management, Vol. 37 No. 4, pp. 336-345. https://doi.org/10.1108/MRR-12-2018-0470

Chen, S. and Huddleston, P. (2009), "A comparison of four strategies to promote fair trade products", International Journal of Retail \& Distribution Management, Vol. 37 No. 4, pp. 336-345. https://doi.org/10.1108/APJML-10-2014-0146

Weisberg, J., Te'eni, D. and Arman, L. (2011), "Past purchase and intention to purchase in ecommerce: The mediation of social presence and Kepercayaan", Internet Research, Vol. 21 No. 1, pp 84. https://doi.org/10.1108/10662241111104893 